\title{
Lessons on Communism: Party Schools in Italy in the 20th Century
}

\author{
Anna Tonelli \\ University of Urbino Carlo Bo
}

\begin{abstract}
The Italian Communist Party created the most effective political school—and the only one in Italy-aimed at creating cadre leaders. The first schools were in Rome and Milan, and over the following decades the school system spread throughout the country, eventually counting about a hundred schools active throughout Italy until 1989.
\end{abstract}

The school in Rome, which was the only one to remain open for a further four years, was the main model for the others. Called the Frattocchie School, it was a residential school in the hills of Rome and was in operation from 1944 to 1993. The students attended classes from six months to a year; they studied historical materialism and the history of Bolshevism but also experienced collective life, group identity, and the theoretical and practical values of communism.

The Frattocchie model began with an initial period in which training consisted of the organization and acculturation of the working classes, starting with workers and peasants, according to a schema influenced by the Soviet schools but where the socializing bent of the Italian institutes mitigated the sectarianism and dogmatism of Moscow.

The aim of the training was to build the careers of future politicians capable of embodying the ideals of a party that demanded control, preparation, and discipline. For this reason, the Italian Communist Party schools represented an original example in teaching methods and curricula, handing down the memory of communism over time. The diaries, questionnaires, and testimonies of the students who attended the Frattocchie School in its 50 years of activity are important sources and a precious heritage to understand how the Communist "faith" became a vehicle of recognition and belonging. Even today the name Frattocchie is associated with a model of party school to be imitated in order to teach methods and principles to those who want to pursue a political career.

\section{Keywords}

Italian Communist Party; political school; historical materialism; memory of communism

The aim of this article is to provide a historical interpretation of the reasons, contents, and transformations of the Italian Communist Party (ICP)'s political

\footnotetext{
* Anna Tonelli, University of Urbino Carlo Bo, Via A. Saffi, 15 - 61029 Urbino (PU), Italy; anna. tonelli@uniurb.it.
} 
school system as an original and innovative model that has no equal in the rest of the world. To reconstruct such a complex and long-lasting phenomenon that provides information on the mechanisms of the training and selection of the leaders at national and local levels, copious and unpublished documentation from the ICP archives held at the Gramsci Foundation was used, together with other material found in the archives of the provincial and local branches, such as circulars, reports, minutes, forms, questionnaires, judgments, and lesson plans. Hundreds of papers have made it possible not only to reconstruct the history of the Communist school system but also to understand how that model represented a new social phenomenon and the cornerstone of a new political culture. It was a system that was not inspired by socialist culture but rather differed from it in its ability to build the foundations of political training based on the study of historical materialism. At the same time, the ICP schools were not simply an imitation of Soviet schools, even though they were aimed at recruiting leaders and educating them politically. Unlike the Moscow model, the Italian school paid more attention to socialization, team spirit, collective study, and respecting discipline but with less rigidity than the Soviet approach. In the Italian case, when we speak of leaders, we mean not only the chief national party leaders but also those middle cadres who were to become points of reference for local realities. Leading figures such as Togliatti, Amendola, Ingrao, Napolitano and, in more recent times, D'Alema and Occhetto taught in the schools. From them, the students learned lessons and examples but also acquired methods and critical awareness. That is why we can conclude that the Italian experience was an original example that deserves to be investigated in all its details and achievements.

\section{Antonio Gramsci's Theoretical and Practical Teachings}

Antonio Gramsci, one of the most authoritative leaders of the ICP, was the first theorist to address the usefulness of political schools in shaping the conscience and profile of militants. In 1919 he set up courses at the School of Culture and Socialist Propaganda (Gramsci 1994, 14) in Turin that were aimed above all at the workers, whose mass ideological preparation was indispensable for moving the revolutionary struggle forward. This goal was derived from the need to counteract the lack of an educational program on the part of the bourgeois family and was to be achieved through extensive work on literacy aimed at the working classes to combat cultural backwardness. The task of the school was to unite the ideological approach with a revolutionary perspective, transforming doctrine into a necessary weapon in the battle for the transformation of society. 
Gramsci also explained in detail how the courses and lessons were to be taught; they were to cover historical materialism, the fundamental elements of general politics, and the organization of the Communist Party. The courses were aimed at all Communist militants and made use of handouts and pamphlets on specific topics (e.g., the question of trade unions, politics, workers, and farmers) with information notes, conversation schematics, and teaching tips for individual and group study. Gramsci also suggested the method of study, with its emphasis on approaching the texts not as simple reading assignments but as material to be studied, striving to assimilate the topics dealt with so as to be able to make reports useful to the party in order to then select the best elements.

Another characteristic of these courses was the solidarity between pupils and the need for mutual help in studying through the formation of groups and the repetition of lessons together in order to avoid the fear and worry of making mistakes typical of less literate and less prepared students. This method introduced and highlighted the pedagogical will of the party and conveyed the value of collective collaboration in the ICP community.

In these first experiments of the 1920s, a model of school was created that was then developed in Gramsci's Prison Notebooks with the insistence on the importance of the critical sense and intellectual discipline for the ideological and political elevation of the workers.

\section{The First Party Schools in the 1940s}

Immediately after World War II, the leading group of the Italian Communist Party decided to make the question of training and political and ideological development of militants a priority. As the return to democracy began, the party that led the antifascist front had to show that it was capable of responding to expectations and of "converting revolutionary aspirations into a new system of values and ideal references that can break with the Fascist past" (Ventrone 2008, 32). The ICP's task was to become a decisive force in the country's reconstruction process and to be part of every aspect of society.

Schools therefore represented one of the most important grounds for creating rootedness, and they became the place for political action and for the training of those who would then be chosen and directed into the central, peripheral, sectional, and cellular party bodies (Bellassai 1999, 87). Just as energy and resources were used in the Resistance for the liberation, so too the schools had to transmit the same spirit of unity and collaboration felt in previous years.

To put this new formula into action, schools had to be residential to accommodate groups of pupils attending courses that could last from six 
months to a year. The students admitted to the first courses tended to be in their early 30 s and the majority were workers and peasants, demonstrating that the aim was to develop and train the lower classes. For this reason, it was essential to have buildings with sleeping quarters, canteens, and classrooms with a library where books, booklets, newspapers, and study materials could be stored. Thus, the housing complex of one of the first national schools, called the Frattocchie (after the name of its location in the hills of Rome), was born and became the model Communist school par excellence that went beyond national borders to become an international reference point-a unique model that had no comparable examples in the rest of the country.

The articles of association codified the aims of the school in four points:

1. To take the schools to a higher political and ideological level

2. To contribute to the training of party cadres specialized in specific fields of knowledge

3. To contribute to knowledge about the current Marxist-Leninist problems in light of the vanguard output of the socialist world

4. To become, through the use of the results of the great national cultural heritage, a center for the study and dissemination of Marxism in the Italian workers', people's, and democratic movement. (Institute of Communist Studies. Program 1955, 3)

All this entailed a considerable investment by the party, which allocated substantial sums each year for overhead that included free boarding and lodging for students, functionaries' salaries, books, medicines, newspapers, wood for heating, and even tobacco. Particular attention was paid to the canteen and food, not only to make sure the caloric intake was adequate for the effort required for studying, but also to show that the schools ensured their students were in the best condition, avoiding food imbalances and discrimination between the better- and worse--off.

The first "commandment" that was imposed was discipline. In a school where pupils had to prove that they were worthy of selection, there were rules and regulations that governed the rhythm of the school day, which lasted from seven in the morning until midnight, with the obligation to fully respect the tasks and rules. "Social work" was also important-that is, material tasks for the good of the community that everyone had to perform in turn, such as cleaning, kitchen duty, gardening, and night security. 
Those who entered a party school knew they had specific responsibilities, duties, and values to respect, as well as hierarchical orders to refer to, in order to be part of an organization where every individual and every moment of life had to flow into a functioning machine that accepted only the obedient militant. In this, political schools were a concrete example of schools of life where behavior, values, and emotions were part of a path that was existential and political.

\section{The Students and the Method of Study}

The aim of the party schools was to select the most suitable subjects to start a political career. For this reason, the party had to carry out a precise reconnaissance with lists and tables indicating the social origin, gender, age, political role, territorial distribution, and degree of culture of each potential student. It also included information on whether the participants were partisans in the Resistance, as proof of combativeness.

Attention was first paid to workers and peasants-that is, to the poorest social classes, as a demonstration of the will to protect, defend, and grow the subordinate classes. This was done through the party's commitment to financing the students' families with the missing salary of the workers who were sent to school and therefore unable to support them.

Before accepting applications, it was necessary to analyze the curricula vitae of the students in terms of their reliability, in order to avoid mistakes and expenditure of energy and finances on people unsuitable for study. Pupils were chosen by the local federations and then sent to the central school for further examination of the candidates. If the applicant's profile was deemed suitable, the student was accepted into the school with no registration or fees to pay because everything was paid for by the party. It became essential to know whether the chosen ones had had a political past and an active role within the Italian Communist Party or a trade union, experience that highlighted the close link between revolutionary practices carried out during the antifascist struggle and the ideological orientations taken as a basis for democratic life.

It is clear that any school undertaking the task of culturally elevating people who had a low level of schooling would find itself in a position of having to provide the fundamentals for a method of study. An ordinary and elementary method was not enough; rather, it was necessary to introduce a series of lessons that would get the students to study in order to understand, discuss, and improve their basic knowledge of the principles of communism and the tenets of the ICP, as well as to be able to speak in public. The cognitive level had to be integrated within a proper strategy that started with studying 
and expanded to cover the overall training of the students. That was why knowledge was indispensable, but it was even more important how this knowledge was developed in a context that made it operational in terms of political action.

The first task was to get people who until then had worked only in the fields or factories used to studying. They had to be taught that they needed to spend an average of eight hours a day on reading, especially collectively, to overcome the difficulties and fears of not being up to such a heavy burden. That was why socalled study brigades were formed, which, as the name suggests, identified with the Bolshevik-style military organization, later borrowed by the Resistance: groups that recognized within themselves the common intent to help each other in the comprehension and discussion of the texts and themes addressed in class. The brigades pursued a double aim: on the one hand, they opposed the bourgeois individualism that led to inevitable competition between the students; and on the other, they defined the Communist solidarity method that led to the achievement of the same result for all students, regardless of the level at which they started. Within this process, however, a clear will to control was also present, with the appointment of a coordinator who supervised the activity of the whole brigade, dealing with potential problems arising during the courses, to prevent quarrels and disparities that could compromise the harmony of the class.

In addition to individual and collective theoretical learning through lectures, conferences, and seminars, there was another field useful for political training: practical work that consisted of the students' participation in the external life of the party, that is, in the sections, cells, trade unions, and factories. Students had to attend meetings and discussions held within these bodies to learn the themes, methods, and language used by the leaders. It was a way to start working in the field and understanding the reality that future officials would have to face once they left the school, with the duty to solve problems and suggest solutions.

The quality of the school, whose aim was to train militants capable of speaking at a meeting, conduct a debate, solve tactical and political issues, and attack or respond to political opponents, was measured by its ability to combine theory with practice. It was a complex but ambitious operation that led the ICP to achieve "mass discipline" (Crainz 2016, 29), which was useful for political purposes.

This structure involved a training project that remained unchanged over time, placing education in politics as a central step in the creation of the socialist society. 


\section{Subjects of Study: Marxism-Leninism and Political Economy}

An ICP school had to consider the subjects and topics its students were to study as fundamental. To develop good Communists and above all capable leaders, it was necessary to begin with Marxist-Leninist theory.

With the aim of raising the political and ideological level of the participants, the study of Marxism lay at the base of all course programs. Palmiro Togliatti $(1944,8)$ believed Marxism to be "the first blow of the pickaxe that paved the way," and it provided the grounding for the political literacy of the masses. To this end, summaries and handouts were prepared that, together with the reading of The Communist Manifesto, introduced lessons aimed at combining theoretical principles with concrete political practice in the field. The teachers themselves reiterated that Marxist theory could not be separated from reality, and thus they explained dialectical and historical materialism through a series of extracts indispensable to the understanding of the theoretical principles summarized in the books: the political struggle of the proletariat, the problem of the state, the struggle against social democracy, and the alliances of the working and peasant classes in the Italian political context. These were topical issues to prompt students to find an interpretation of the present.

However, familiarizing workers and peasants with the sacred texts of communism was not a simple task. Teachers used elementary language and a series of metaphors to explain complex concepts. The greatest obstacle was the lack of acculturation of the students who, often having only completed primary school, found it difficult to follow the lessons and assimilate the texts. For this reason, it was decided to include the Italian language as a permanent subject in the courses, to avoid using dialect, and to bring everyone to the same linguistic level, in order to obtain better results even in written exercises that often had spelling and grammatical errors and evidenced a poor mastery of the "key words of communism" (Bassi 2019, 10).

Once the cardinal principles of Marxism-Leninism were acquired, students moved on to learn the historical and political background. A substantial part of the courses concerned two central issues: the history of the Communist Party in the Soviet Union and the history of the Italian Communist Party, as linked to the history of Italy. With respect to the first theme, it can be seen that even in the schools the study of a reality judged as a unique model and driving force for the realization of communism had to be central (Flores 2017, 27). The second served to build the identity of the students, who started with the birth of the workers' movement and ended in the present with a historical perspective capable of giving guidance for the party's struggle and political approach. 
To better assimilate Marxist ideology within a more accomplished secular culture, it was necessary to appreciate the subjects that were part of the "new proletarian science," as happened in the Soviet Union in the mid-1950s, in a period of great expansion of technological achievements (Cassata 2008, 10). The natural sciences-biology, geography, and mathematics-were included to help students avoid prejudices and false information produced by the enemy's propaganda, starting with the Americans. That was why science could and had to become everyone's heritage, to open minds and decipher complex realities that could not be left only to a minority or, even worse, propagandized as an anti-Communist weapon.

The study of all these subjects, which formed a precise and solid revolutionary program, required that the lesson on any topic was carried out in three stages: to start with, the teaching staff elaborated the theme with the setting of the questions and the minimum required reading; then the students applied themselves to individual study for a week; at the end there was a collective discussion between the students, followed by a conclusion by the teacher. This was a fixed schema for each theme, for up to nine or ten topics for a sixmonth course. At the end of each course an essay had to be written by the students on a subject agreed to after the seminar, as a useful exercise for future political work: here how quickly the students grasped the crux of the matter, the correctness of their writing and syntax, and their ability to transform concepts into tools for political action were evaluated.

With a view to political employment, the school promoted the study of political economics. To decipher the complexity of the tasks required, specialized courses in political economics that dealt with production relations, the various economic structures, the development of capitalism up to the era of financial capital, and the growth of monopolies became indispensable. These were very difficult subjects for the students, but they accepted that they had to apply themselves to such a demanding course load because they considered it necessary for the work they would have to do outside the school. Those who would have to lead a municipality or manage a cooperative, for example, had to understand the theoretical principles so as to transform theory into effective strategic plans.

Economic studies were even more necessary in the 1970s with the international economic crisis that severely affected Italy. Topical issues such as oil production and distribution in the Middle East, inflation, developing markets, production decline, and workforces were covered in order to provide all the information needed to understand the current problems and to try to implement concrete measures and responses. In this the school system proved 
to be adaptable and ready to accept the transformations of the world that were inevitably also reflected in the training methods.

In addition to economics, elements of mathematics, law, geography, and science were introduced (in one course a scientist explained how the atomic bomb was discovered and how it worked), with speakers from within and outside the school.

In the 1970s linguistics once more occupied an important place in the curriculum, as an indispensable tool to master a clarity of language that the students needed. The authoritative linguistics scholar Tullio De Mauro (1977, 26) was invited to speak at the Party School Conference to encourage students to "understand and make [themselves] understood." Knowing how to use words effectively was a way for students to show that they were ready to take on political and administrative roles outside of the classroom. The refinement of language, therefore, was one of the necessary aspects in a training aimed at achieving an autonomy of thought and action in the students.

Throughout the duration of the schools, the main subjects taught remained unchanged, even if the period of study changed, from six to three months to even one month, as the ICP needed to move trained leaders into the field.

\section{Collective Life at the Schools}

The ICP schools aimed not only to raise the ideological and cultural level of its students, but also to form their character and moderate their defects in order to influence their behavior in the classroom, their relationships with others, and the quality of collective life. Thus, character and temperament were some of the essential parameters to be evaluated in order to understand whether certain of the student's characteristics were compatible with a long period spent together with others and, at a later stage, whether the defects manifested were attenuated, and in what way, both of which needed to be assessed during the course of attendance. Determination and willpower, together with calmness and sociability, were some of the qualities a good politician ought to develop, while impulsiveness and emotionality became a hindrance to good performance at school and thus to a potential political career.

The party did not limit itself to recording merits and defects; it also took on the task of correcting character distortions, dictating the rules of behavior, and exalting the functional aspects for the success of the course. A student's personality was important, but the willingness to "be changed" was also evaluated positively. The correction of one's own defects was proof of a desire for improvement, as well as a sign of being able to adapt to the required model. Militants who recognized that they had made mistakes exhibited a guarantee 
of obedience and discipline and therefore embodied the ideal Communist (Bellassai 2000, 50).

It was Palmiro Togliatti himself, in the role of secretary and charismatic leader, who insisted on the priority of the formation of the students' character:

At the school you should not only study, at the school you should not only pay attention to the practical work. At the school we not only solve problems of culture, at the school we also solve problems regarding the character formation of our comrades and the temperament formation of our leaders. That is why a party organization must be active and functional at the school from the first day to the last and, for this reason, a party tradition must be introduced in the relationships between teachers and professors and in the relationships between comrades, between the students themselves, and between the students and the leaders (Togliatti 1949, 4).

Working on the students' "mettle" meant building a solid structure where everyone was called to play their part, to improve the individual and, consequently, the collective. If students were able to recognize their limits, it meant that they had reached full Marxist-Leninist maturity and were therefore worthy of participating in the courses and to be counted among those predestined for political progression.

Two qualities were judged to be the best in assessing the character of students: seriousness, as a form of responsibility, and sociability, adapted to the spirit of the group. From the merging of these two values came the profile of the student who exhibited a serious, discreet, and sociable character and was thus deemed mostly likely to be a future good political leader. By contrast, an impulsive, susceptible, presumptuous character did not prelude important future jobs because it meant that the subject evaded discipline and did not know how to adapt to the ideals and rules imposed by the party. Furthermore, character limits posed a threat to the harmony of the group, and therefore immediately alerted leaders and teachers, who could no longer control the class. In fact, in cases of "bad character," the school's reparative role was decisive, measuring its success in the improvement of the qualities of character that, together with those of learning, formed the personality of the student.

The predisposition to correct one's own defects was one of the essential requirements to guarantee the quality of collective life, another backbone of the school. The correct and fraternal relationship between the students avoided creating divisions by age and origin and separating the young and old, or the more and less educated. The harmony and cohesion between students, the ability to adapt to the required tasks, the distribution of those tasks, and the 
mutual support in lessons and exercises were as decisive as performance in study.

It is no coincidence that the students were discharged with a summary sheet, a type of report card that evaluated progress together with behavior in the classroom, character, and the ability to integrate into the collective, all of which determined the final result.

Individual requisites to be calculated included personal aspects (intelligence, stated using variables in the positive- "open," "lively," "fairly well trained"and negative- "insufficiently critical," "not elastic enough," "reflective but a little slow"), as well as educational (general culture) and political (political experience) details. In addition, each student's ideological level was assessed, together with the student's commitment to work hard to fix any deficits.

As with a traditional school report card, the subjects of study were included, which focused on six teaching areas with a Communist Party root: political economics, theoretical foundations of Marxism-Leninism, problems of the party and the proletarian revolution, history of the international workers' movement, history of the ICP and the struggles of the Italian working class, and national ICP politics and its application. The performance in each of these subjects was assessed on a monthly basis using a traditional scale of grading (insufficient; sufficient and sufficient+; fair; good; excellent) up to the end of course grade and the final examination. The improvement in grade contributed to the evaluation highlighting progress in learning the study method and overcoming schematism and prejudices.

Both teachers and students had a stake in the success of the training course because the goal was the same for both, and every failure was a defeat for everyone.

Students were also questioned about the school and had to express their opinion on the courses and teaching methods (Boarelli 2007, 34). For this purpose, questionnaires and assignments were distributed that contained questions about the quality of the schools and the experience gained during class attendance. In reviewing a sample of students' responses to these questions, it is clear that often a predetermined judgment was offered: a feature found in the opinions of all students who felt gratified to have participated in the courses of the policy schools. Students were expected to be enthusiastic about the training they had received in order to be judged as "good communists." They were expected to be grateful and ready to repay the debt with a commitment to practical activity when they returned to their communities. An example from a student in a Bologna ICP school typifies this response: 
We had the great honor of being admitted to one of the party schools, for a three-month course and it is an honor because it is the greatest prize and the greatest satisfaction for a communist to be able to improve his skills through continuous and methodical study as is used here.

No student skimped on hyperbole in reference to their individual growth and progress, thanking the party for the opportunity offered.

\section{The Crisis of the Political School Model}

The ICP school system ended with the collapse of the Berlin Wall in 1989 and the subsequent crumbling of the Communist world; however, it began to show the first symptoms of disintegration in the early 1980s. During that period the ICP, too, had to deal with political indifference and the estrangement from political commitment that traversed important slices of the progressive culture.

ICP Secretary Enrico Berlinguer's strategy of the "democratic alternative" after the breakaway from Moscow, facilitated by the invasion of Afghanistan and General Wojciech Jaruzelski's coup d'état in Poland, was unable to attract very large numbers of interested new party members and ended up leading the ICP to an increasingly evident isolation. This setback, made even worse by the decreased enrollment, led to a crisis in the schools and a rethinking of the ICP's education system. With fewer investments in financial terms, it was decided to abandon the model of the residential schools, which were deemed too costly, and to shorten the length of courses to two or three days.

Above all, it was necessary to change the themes covered in the schools, resulting in the downsizing of the classics of Marxism in favor of in-depth studies linked to modernity or in any case in tune with a world that was radically changing. A method that no longer corresponded to reality, in a political and cultural situation in turmoil, was more or less explicitly criticized. The previous approach of the schools, considered an old legacy of the ideological party, was contested, especially by young people, who called for a modernization based on new content and themes such as the environment, ecology, mass communication, health, and participation. The suggestion was to focus on specialized topics, analyzed by experts able to offer a stimulus directly related to the work they carried out. International issues also came in as the basis of a politics that had to look outside its own borders to find a place and support within the perimeters of the redefinition of European and non-European societies.

Even the party's leaders rejected the old method marked by dogmatism and schematism to embrace the idea of a school open to confrontation and a 
relationship with a contemporary culture that could no longer be interpreted and taught using traditional teaching tools. This represented a change that not only responded to the crisis of the schools, but also attempted to include new ways of learning and understanding by a party increasingly detached from a reality that had adopted new values and languages.

The aim was to transform students into cadre leaders capable of bringing specialist research into the culture of the party. The schools therefore had to aim to provide a modern political education capable of incorporating much of the knowledge of the modern world and of guaranteeing skills and values within the concreteness of political action.

This direction coincided with the different types of students attending the schools. The number of blue-collar workers and farmers decreased, and the number of students, office workers, and technicians increased, especially those with higher levels of schooling, many of them being college graduates.

The collapse of the international communist empire and the crisis of the old political system that forced the winding up of the ICP had disastrous consequences on the schools. The transformation of the ICP into the Democratic Party of the Left also resulted in the end of the schools and the selling of the Frattocchie complex in Rome in 2003 to a group of private entrepreneurs. Thus, on the ICP's political schools, "a silence [fell], heavy as volcanic ash" (Falconi 2016, 272).

\section{The Legacy of Communist Schools}

Even after the end of communism, political schools remained a model of inspiration. Once faith in ideologies collapsed, the decline of the traditional structure of the parties and the political cultures to which they belonged began. However, the new movements and parties that appeared on the public scene at the dawn of the 21 st century inevitably faced the problem of choosing and training their leaders. The heirs of the Italian Communist Party or even new actors in contemporary politics recognized the validity of the schools as a legitimate place for the selection of new recruits for political careers. Almost like a paradox in times of the devaluation of political competences, parties, movements, associations, and foundations continued to call for places and sessions where young people and militants could be trained in the rudiments of politics. Just about anything can lie behind the definition of a political school, however, with objectives far removed from a pure and complex educative approach. In many cases it is simply a matter of designations from the top, measuring consensus with leaders, training in political communication, and 
fundraising systems. Some political scientists have used the term nonplaces in reference to the training of leaders (Coccia 2016, 5).

However, these are models that have little or nothing to do with the laboratories of the past, starting with the ICP universe of the Frattocchie. There is practically nothing left of that system, positive or negative, except the evocation of the name. The political schools of this millennium actually consist of short stays and courses where young militants go to listen to speakers and take part in debates on some contemporary political issues. In these didactic experiences, seminars, lectures, and courses lasting a few days seem to be used more for co-optation than for training, a very different project and far from the experiences of the 20th century. Education in politics represented for the ICP a verification of its pedagogical roots by interweaving the directives from above and the experience from below, the teaching and study methods, and the reception they had from the students.

To retrace the history of political education processes means to start by understanding the past in order to strengthen critical interpretations that are not satisfied with superficial passages but need to be in depth to understand the roots of political cultures and the traces they left as a theoretical and recollection heritage. Only in this way can such a complex and long-lasting experience be restored to its proper historical context, far from any possible nostalgic drift toward reference to a type of politics that has now radically distorted connotations.

There is no need to resort to the Ciceronian historia magistra vitae, but it is certain that the tools of history help to understand the complexity of the present, offering interpretations that are also indispensable for politics. If party leaders propose training political personnel without the fundamentals of historical and political culture, they cut out a central part of the educational and political project. As Eric Hobsbawm $(1994,144)$ explained, in this way we cannot discern "what the nineteenth century would have called 'progress' and 'reaction'-only that these terms were no longer quite apposite"-a reflection that also applies to political schools of the past and the present.

\section{Conclusion}

Today's political parties continue to train future leaders, but with new tools such as the web, social media, and digital platforms. Politics has changed radically, but so has recruitment, which no longer involves selection based on skills and learning, but on the ability to be visible, to use digital communication, and to attract followers. For this reason, the Italian Communist Party schools of the 20th century represent a model of the past, in some cases even envied 
by their political adversaries (starting with the Christian Democrats) but no longer imitable or feasible. Even where they do exist, political schools have completely lost their educational value and have instead become a selfreferential place where people go to be counted and promote themselves. Studying a phenomenon of the past is therefore useful not only to grasp the differences but also to identify the characteristics of contemporary politics, which increasingly focus on the personalization of leaders and the designation of activists based on loyalty and the repetition of slogans and identifying traits of movements and parties.

\section{References}

Agosti, Aldo. 2009. Il partito mondiale della rivoluzione. Saggi sul comunismo e l'Internazionale [The world revolutionary party: Essays on communism and the Third International]. Milan: Unicopli.

Andreucci, Franco. 2005. Falce e martello. Identità e linguaggi dei comunisti italiani fra stalinismo e guerra fredda [Hammer and sickle: Identity and language of the Italian communists between Stalinism and the Cold War]. Bologna: Bononia University Press.

*Bassi, Giulia. 2019. Non è solo questione di classe. Il "popolo» nel discorso del Partito comunista italiano (1921-1991) [Not just a question of class: The "people" in the Communist Party discourse (1921-1991)]. Rome: Viella.

*Bellassai, Sandro. 1999. "The Party as School and the Schools of Party: The Partito Comunista Italiano 1947-1956." Paedagogica Historica. International Journal of the History of Education, n. 1.

*Bellassai, Sandro. 2000. La morale comunista. Pubblico e privato nella rappresentazione del $P C I$ [Communist morality: The public and private in the representation of the ICP]. Rome: Carocci.

*Boarelli, Mauro. 2007. La fabbrica del passato. Autobiografie di militanti comunisti (1945-1956). [The factory of the past: Autobiographies of Communist militants (1945-1956)]. Milan: Feltrinelli.

*Cassata, Francesco. 2008. Le due scienze. Il "caso Lysenko» in Italia [The two sciences: The "Lysenko case" in Italy]. Turin: Bollati Boringhieri.

*Coccia, Benedetto. 2016. I "non luoghi" della formazione della classe dirigente e della decisione politica [The "non-places" of leadership training and political decision-making]. Rome: APES.

${ }^{*}$ Crainz, Guido. 2016. Storia della Repubblica. L'Italia dalla Liberazione a oggi [The history of the Republic: Italy from its liberation to today]. Rome: Donzelli.

${ }^{*}$ De Mauro, Tullio, 1977. Formazione dei quadri e sviluppo del partito [Cadre training and the development of the party]. Minutes of the Fifth National Conference of the Party Schools Central Section. Rome: La Tipografia Moderna.

De Mauro, Tullio. 2014. Storia linguistica dell'Italia repubblicana dal 1946 ai nostri giorni [The linguistic history of Republican Italy from 1946 to the present day]. Rome: Laterza. 
*Falconi, Graziella. 2016. Una magnifica ossessione. La vocazione pedagogica del PCI [A magnificent obsession: The pedagogical roots of the ICP]. Rome: Harpo.

Fiocco, Gianluca. 2018. Togliatti, il realismo della politica. Una biografia [Togliatti, the realism of politics: A biography]. Rome: Carocci.

*Flores, Marcello. 2017. La forza del mito. La rivoluzione russa e il miraggio del socialismo [The power of myth: The Russian revolution and the mirage of socialism]. Milan: Feltrinelli.

Flores, Marcello, and Nicola Gallerano. 1992. Sul PCI. Un'interpretazione storica. [On the ICP: A historic interpretation]. Bologna: Il Mulino.

Gramsci, Antonio. 1978. Scritti politici [Selections from political writings]. Rome: Editori Riuniti.

*Gramsci, Antonio. 1994. Per una preparazione ideologica di massa. Introduzione al primo corso della scuola interna di partito. Aprile-maggio 1925 [For mass ideological preparation: Introduction to the first course of the internal party school, April-May 1925]. Naples: Edizioni Laboratorio Politico.

${ }^{*}$ Hobsbawm, Eric. 1994. The Age of Extremes: The Short Twentieth Century, 1914-1991. London: Michael Joseph.

Ilardi, Massimo, and Aris Accornero. 1981. Il Partito comunista italiano. Struttura e storia dell'organizzazione, 1921-1979. [The Italian Communist Party: The structure and history of the organization, 1921-1979]. Milan: Feltrinelli.

Istituto di Studi Comunisti [Institute of Communist Studies]. 1955. Programma dei corsi di studio e dei seminari [Program of courses of study and seminars]. Rome: Editori Riuniti.

Lussana, Fiamma. 2007. In Russia prima del Gulag. Emigrati italiani a scuola di comunismo [In Russia before the gulag: Italian emigrants at the Communist school]. Rome: Carocci.

Marijnen, Anne. 1996. "Entrée en politique et professionnalisation d'appareil. Les écoles centrales de cadres du Parti communiste italien (1945-1950)" [Entry into politics and the professionalization of structure: The central schools for cadres of the Italian Communist Party (1945-1950)]. Politix 35, 89-108.

Marino, Giuseppe Carlo. 1991. Autoritratto del PCI staliniano, 1946-1953 [Self-portrait of the Stalinist ICP, 1946-1953]. Rome: Editori Riuniti.

Pons, Silvio. 1999. L'impossibile egemonia. L'URSS, il PCI e le origini della guerra fredda, 1943-1948 [The impossible hegemony: The USSR, the ICP and the origins of the Cold War, 1943-1948]. Rome: Carocci.

Pons, Silvio 2012. La rivoluzione globale. Storia del comunismo internazionale, 1917-1991 (The global revolution: A history of international communism, 1917-1991). Turin: Einaudi.

*Togliatti, Palmiro. 1944. "Programma” [Program]. Rinascita 1, 5-15.

*Togliatti, Palmiro. 1949. "Per la formazione dei quadri" [For the training of cadres]. Rinascita 8, 17-22.

*Ventrone, Angelo. 2008. La cittadinanza repubblicana. Forma-partito e identità nazionale nelle origini della democrazia italiana (1943-1948) [Republican citizenship: Party-form and national identity in the origins of Italian democracy (1943-1948)]. Bologna: Il Mulino.

Vittoria, Albertina. 2006. Storia del PCI, 1921-1991. [History of the ICP, 1921-1991]. Rome: Carocci. 
Journal of Nationalism, Memory \& Language Politics 15(1) 